\section{Another human chimaera}

Summary. Another human chimaera is described, which we are unable to classify because of limited family data. Evidence of chimaerism was confined to haemopoietic tissues. There were two red cell populations with differences in four blood group systems and, although the patient was female, chromosome analysis of cultured lymphocytes showed that $96 \%$ of cells had the male karyotype 46,XY. Possible mechanisms for the production of chimaeras are discussed.

The chimaera of Greek mythology was a firebreathing 'she-monster' with a lion's head, a goat's body, and a dragon's or snake's tail. In biology, however, a chimaera is an organism which has a mixture of cells of different genetic constitution.

The example which we describe here was found, as were most previous examples (Race and Sanger, 1968; Crookston, Tilley, and Crookston, 1970; Kaeser and Nennstiel, 1971), as the result of difficulty in blood grouping.

\section{Case report}

The red blood cells of the proposita, a 22-year-old Caucasian prima gravida, who had never been transfused, were found on routine antenatal serological investigation to give 'mixed-field' reactions with various antisera. There are many different causes of 'mixed-fields' (Race

Received 31 December 1973. and Sanger, 1968; 1972). Clinical, haematological, and serological investigation eliminated all known causes except chimaerism. The patient is physically and psychologically female; and, according to her mother, is not a twin. Both her eyes are of the same colour, and she has no other signs of dimorphism, eg patches of lighter and darker coloured skin, or of intersexuality. During our investigation she was delivered of a healthy baby boy.

Blood groups and secretion. The results of ABO and Rhesus tests (Table I) showed that two red cell populations were present, one of which was group $O$, the other $A_{1}$. The two populations were therefore separated by using the powerful anti- $A_{1}$ agglutinin from the seeds of Dolichos biflorus (Bird, 1951). The method used was the same as that described by Booth et al (1957), except that the $A_{1}$ cells were disagglutinated with a $1 \%$ aqueous solution of $\mathrm{N}$-acetylgalactosamine. The two cell populations were extensively grouped and found to differ in four blood group systems:

$$
\text { Major population. } \mathrm{O}, \mathrm{MN} \text {, cde/cde, } \mathrm{Fy}(\mathrm{a}-) \text {. }
$$

Minor population. $\mathrm{A}_{1}, \mathrm{NN}, \mathrm{CDe} / \mathrm{cde}, \mathrm{Fy}(\mathrm{a}+)$.

Professor P. L. Mollison carried out differential agglutination tests and estimated that there were about $93 \%$ group $\mathrm{O}$ and $7 \% \mathrm{~A}_{1}$ red cells.

When the proposita was pregnant, she was found to secrete $A, H$, and Lewis $\left(L^{a}\right)^{a}$, but not $L^{b}{ }^{b}$ substance in her saliva. Since $\mathrm{Le}^{\mathrm{b}}$ is known to be an interaction product of $\mathrm{H}$ and $\mathrm{Le}^{\mathrm{a}}$, we assumed that the $\mathrm{H}$ and $\mathrm{Le}^{\mathrm{a}}$ substances were produced in separate cell lines and therefore did not interact to form Le ${ }^{b}$. After delivery however, she was found to secrete $L^{b}{ }^{b}$, so this attractive idea had to be abandoned. We mention it only to warn others, who might make such an observation, against making a similar mistake in interpretation. The findings before delivery were probably due to a quantitative reduction during pregnancy (Brendemoen, 1952; Rosenfield et al, 1960).

TABLE I

BLOOD GROUPS

\begin{tabular}{|c|c|c|c|c|c|}
\hline ABO-Red cells against sera: & $\begin{array}{c}\text { Anti-A } \\
+ \\
\text { (Mixed-field) }\end{array}$ & $\begin{array}{c}\text { Anti-A } \\
+ \\
\text { (Mixed-field) }\end{array}$ & $\underset{-}{\text { Anti-B }}$ & \multicolumn{2}{|c|}{$\begin{array}{c}\text { Anti-(A+B) } \\
+ \\
\text { (Mixed-field) }\end{array}$} \\
\hline ABO-Serum against red cells: & A & $\begin{array}{c}\mathbf{B} \\
+++\end{array}$ & $\underline{0}$ & \multicolumn{2}{|c|}{ OWN } \\
\hline Rhesus-Red cells against sera: & $\begin{array}{c}\text { Anti-C } \\
+ \\
\text { (Mixed-field) }\end{array}$ & $\begin{array}{c}\text { Anti-D } \\
+ \\
\text { (Mixed-field) }\end{array}$ & $\underset{-}{A n t i-E}$ & $\begin{array}{l}\text { Anti-c } \\
+++\end{array}$ & $\begin{array}{l}\text { Anti-e } \\
+++\end{array}$ \\
\hline
\end{tabular}




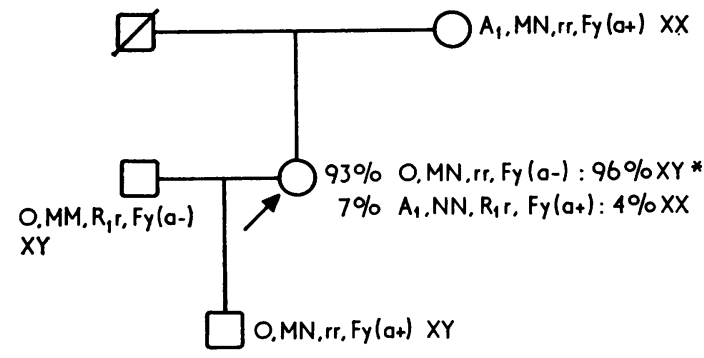

Fig. 1. Blood groups and blood cell karyotypes of the proposita $(\nearrow)$ and her family.

* The major lymphocyte population is not necessarily of the same genetic origin as the major erythrocyte population.

\section{Family study}

Unfortunately, the proposita's father is dead and there are no sibs. Her mother, husband, and child were tested; the results, confined to lymphocyte 'sexing' and the four blood group systems pertinent to this study, are shown in the family tree (Fig. 1).

The proposita's baby is Fy(a+). Hence an assortment of genes from chromosomes determining the minor population of the proposita's red cells have been transmitted to her child. The $R_{1}(C D e)$ chromosomes of the minor population must have been derived from the proposita's father because her mother is $r r(c d e / c d e)$. Since the major population of the proposita's red cells is $r r$, her father's Rhesus genotype must have been $R_{1} r$; his genotypes in the other three systems cannot be accurately deduced.

Other markers. HL-A typing (lymphocytotoxicity) by Mrs L. P. Mackintosh showed no evidence of two cell populations; in view of the small proportion of the lesser cell population, this is not surprising. Dr E. B. Robson of the Galton Laboratory studied the following red cell markers on separated cells: phosphoglucomutase locus 1 (PGM1), adenylate kinase (AK), adenosine deaminase (ADA), pepsidases (A, B, C, and D), esterase D (ES-D). No evidence of dimorphism was found in these studies, or in an investigation of $\mathrm{Gm}$ status by Miss D. F. Barr.

TABLE II

RESULTS OF CHROMOSOME ANALYSIS ON THE PROPOSITA

\begin{tabular}{l|c|c}
\hline \multirow{2}{*}{ Culture } & \multicolumn{2}{|c}{ No. of Cells } \\
\cline { 2 - 3 } & $46, \mathrm{XX}$ & $46, \mathrm{XY}$ \\
\hline Lymphocyte 1 & $3(2 \%)$ & 147 \\
\hline Lymphocyte 2 & $5(5 \%)$ & 95 \\
\hline Lymphocyte 3 & $5(5 \%)$ & 95 \\
\hline Fibroblast 1 & $30(100 \%)$ & 0 \\
\hline Fibroblast 2 & $52(100 \%)$ & 0 \\
\hline
\end{tabular}

\section{Cytogenetics}

Chromosome analysis. Results of chromosome investigations on the proposita are given in Table II.

Analysis of cultures of blood taken on three occasions revealed the presence of two cell lines with the normal karyotypes, 46,XX and 46,XY. Approximately $96 \%$ of the cells examined contained the male karyotype 46,XY. The distal portion of the long arms of the $\mathrm{Y}$ chromosome showed the typical intense fluorescence when stained with quinacrine dihydrochloride (Fig. 2).

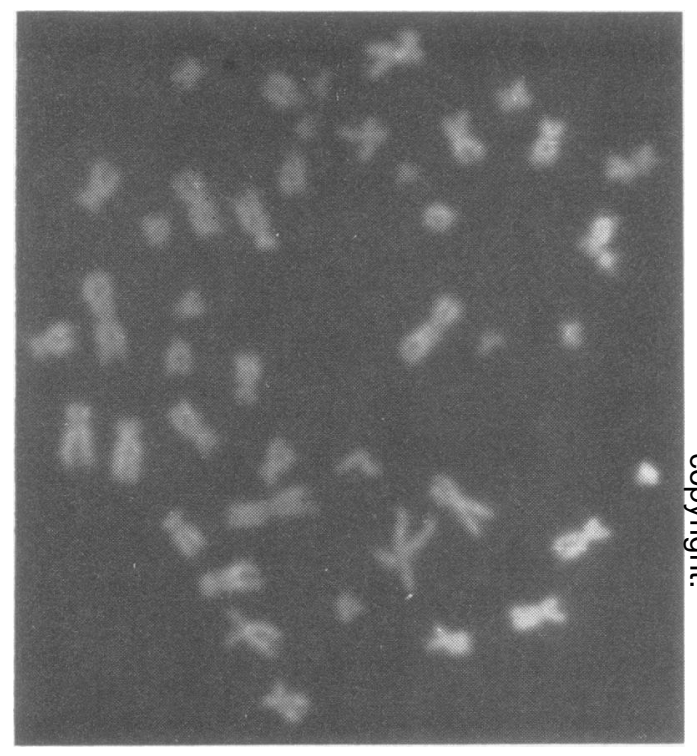

FIG. 2. Male karyotype from lymphocyte culture of the proposita showing fluorescent $\mathrm{Y}$-chromosome on periphery of cell.

The two karyotypes, banded by the trypsin Giemsa technique are illustrated in Figs. 3 and 4 . Only cells with the female karyotype, $46, \mathrm{XX}$, were found in the fibroblast cultures established from a skin biopsy.

Examination of blood cultures from the proposita's mother and son revealed normal female and male karyotypes, respectively.

Nuclear sexing. Buccal smears screened for X-chromatin were $19 \%$ chromatin-positive (96/500). Examination of blood films revealed only four drumsticks in 840 polymorphs examined (approximately $0.5 \%$ ). 


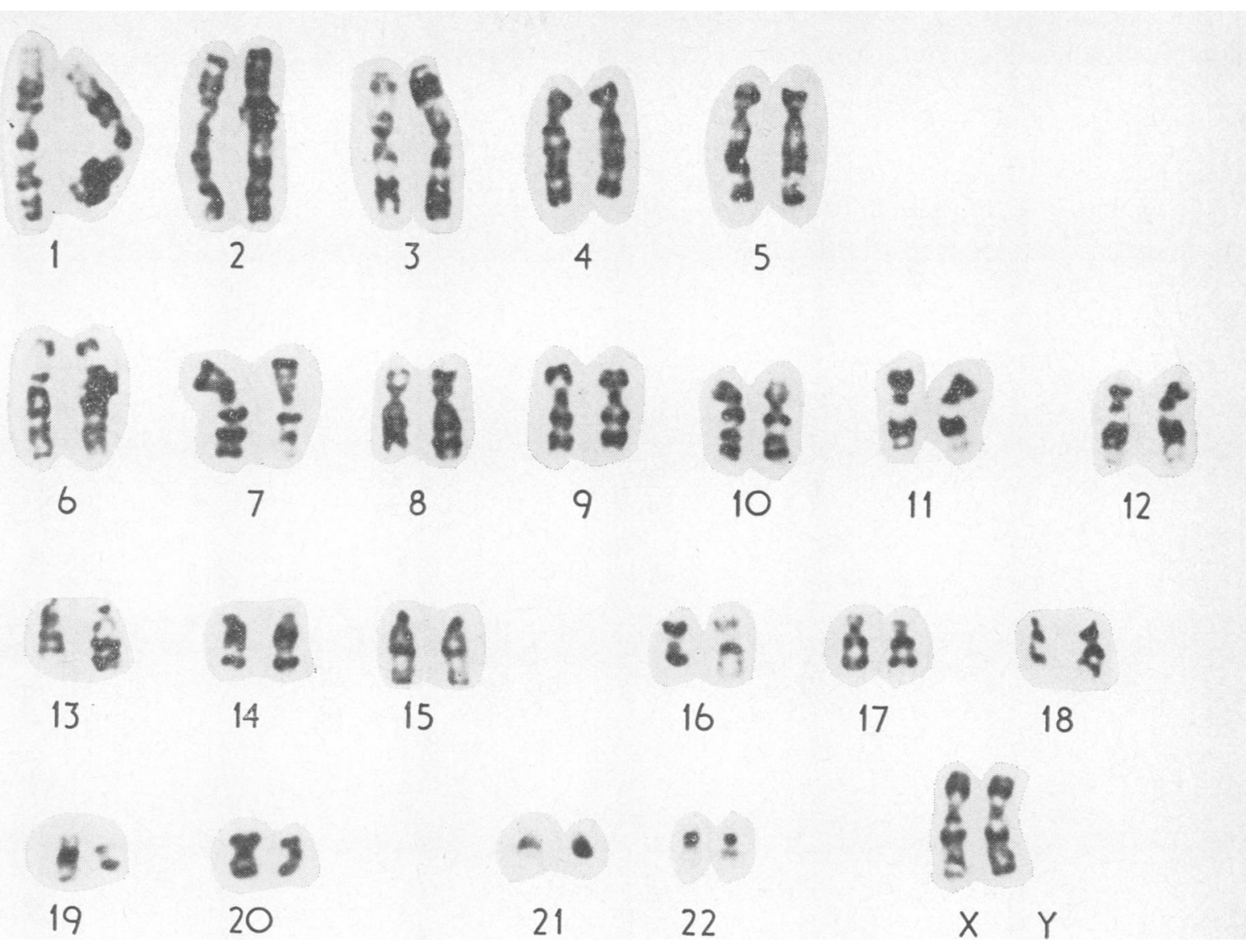

FIG. 3. Giemsa-banded $46, \mathrm{XX}$ karyotype from lymphocyte culture of the proposita.

Extensive examination of buccal, vaginal, and cervical smears by the quinacrine fluorescence technique failed to reveal the presence of any $\mathrm{Y}$-chromatin bodies in these tissues. The fluorescent $\mathrm{Y}$ body was observed, however, in approximately $13 \%$ of white cells in blood smears (40/300).

\section{Hormones}

The plasma testosterone was $107 \mathrm{ng} / 100 \mathrm{ml}$. and the 4 androstenedione was $162 \mathrm{ng} / 100 \mathrm{ml}$. These estimates are within the normal range for a female.

\section{Discussion}

Since the first description of a twin chimaera (Dunsford et al, 1953), and of a dispermic chimaera (Gartler, Waxman, and Giblett, 1962), several more of each kind have been studied (Race and Sanger,
1968; Ford, 1969; Giblett, 1969; Crookston et al, 1970). R. R. Race and R. Sanger (personal communication, 1973) know of 16 examples of twin chimaeras and 19 of dispermic chimaeras. As far as we know, our patient has a much higher percentage of $46, \mathrm{XY}$ lymphocytes than any female chimaera previously reported.

It is quite clear that an overwhelmingly male constitution of lymphoid or possibly all haemopoietic tissue is quite compatible with the female state, and supports the view of Uchida, Wang, and Ray (1964) that the proportion of XX to XY in blood has no relevance to sex characteristics.

Although well over $90 \%$ of the lymphocytes were $\mathrm{XY}$, and over $90 \%$ of the red cells were a distinct majority, it is possible that the red cell majority represents an XX line. The limited evidence that the polymorphonuclear cells have unusually few drumsticks (about $0.5 \%$ ) against an expectation of 


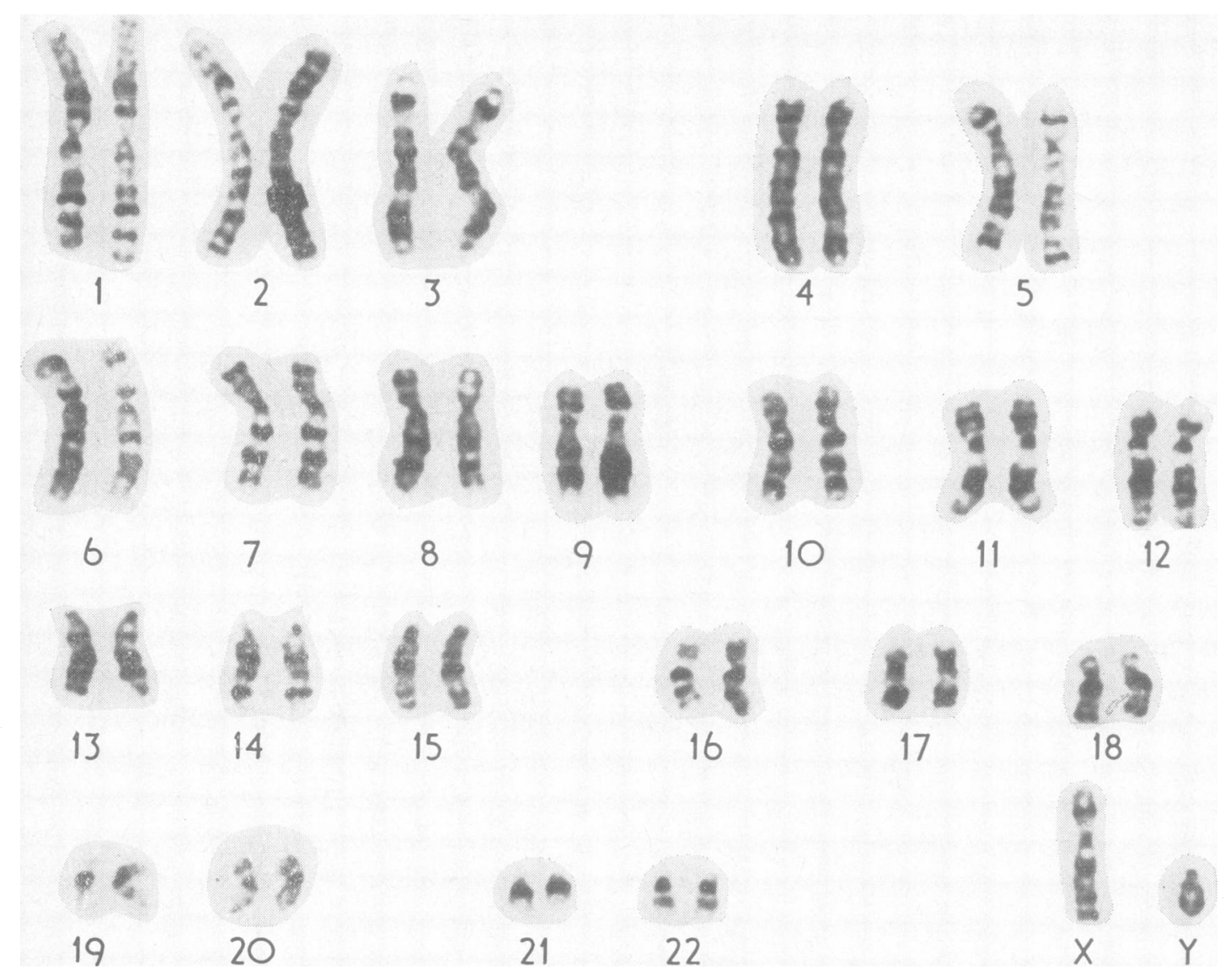

FIG. 4. Giemsa-banded 46,XY karyotype from lymphocyte culture of the proposita.

$1-3 \%$ suggests the myeloid series also has an $\mathrm{XY}$ preponderance. This would be consistent with the simplest explanation of a generalized male preponderance in all lymphoid and haemopoietic tissues. Unfortunately, several attempts to define the Y-body in blood films were unsatisfactory.

Ford (1969) discussed nine possible mechanisms for the formation of human chimaeras. They may be divided into two groups: the first, which results from two separate acts of syngamy involving one ovum, and the second, which results from the intermixture or exchange of cells between individuals of different zygotic origin. The data available in the present case restrict consideration of the mechanisms involved to two types from each group: from the first, (1) dispermy with participation of the ovum nucleus and the nucleus of the second polar body or
(2) dispermy with participation of two haploid nuclei, daughters of the ovum nucleus; and from the second, (3) early fusion of two embryos, or (4) placental cross-circulation between dizygotic twins.

In (1) the genotypes of the two maternal contributions would be different, and in (2) identical. Since the proposita's father was not available for study, we can make no full assessment of paternal and maternal gene contributions.

In (3), the early fusion of two embryos would result in an intimate mixture of the two cell types, potentially affecting all tissues. Although it cannot be excluded, the apparent absence of the $46, \mathrm{XY}$ cell line from all tissues examined cytogenetically, except the blood, does not support this mechanism as the origin of the present chimaera. Mechanism (4), the cross-circulation between dizygotic twins 
with subsequent loss or absorption of one twin, remains a possibility. A comparison of the chromosome G-bands of the proposita and her mother was not informative in attempts to elucidate the mechanism involved by cytogenetic means.

A further possible explanation of chimaerism in haemopoietic tissue alone may be a fusion of the primitive circulations of two yolk sacs, since the yolk sac is one of the earliest sites of haemopoiesis (D. I. Rushton, personal communication).

We are indebted to many of our colleagues for expert advice; some are mentioned above. We also gratefully acknowledge the valuable help and advice of Pauline Mackintosh, Professor J. H. Edwards, Professor D. G. Harnden, Drs R. R. Race and Ruth Sanger, Dr A. H. Cameron, Dr I. D. O. Frew, and Dr J. Insley.

\section{Diana A. Battey, G. W. G. Bird, A. McDermott, C. W. Mortimer, O. M. MUTCHINICK, and JUNE WINGHAM}

\section{Regional Blood Transfusion Service, Birmingham, the Good Hope General Hospital, Sutton Coldfield, and the Department of Human Genetics, University of Birmingham}

Bird, G. W. G. (1951). Specific agglutinating activity for human red blood corpuscles in extracts of Dolichos biflorus. Current Science, 20, 298-299.

Booth, P. B., Plaut, G., James, J. D., Ikin, E. W., Moores, P., Sanger, R., and Race, R. R. (1957). Blood chimerism in a pair of twins. British Medical fournal, 1, 1456-1458.

Brendemoen, O. J. (1952). Some factors influencing Rh immunization during pregnancy. Acta Pathologica et Microbiologica Scandinavica, 31, 579-583.

Crookston, M. C., Tilley, C. A., and Crookston, J. H. (1970). Human blood chimaera with seeming breakdown of immune tolerance. Lancet, 2, 1110-1112.

Dunsford, I., Bowley, C. C., Hutchison, A. M., Thompson, J. S., Sanger, R., and Race, R. R. (1953). A human blood-group chimaera. British Medical fournal, $2,81$.

Ford, C. E. (1969). Mosaics and chimaeras. British Medical Bulletin, 25, 104-109.

Gartler, S. M., Waxman, S. H., and Giblett, E. R. (1962). An

- XX/XY human hermaphrodite resulting from double fertilization. Proceedings of the National Academy of Sciences, 48, 332-335.

Giblett, E. R. (1969). Genetic Markers in Human Blood. Blackwell Scientific, Oxford.

Kaeser, A. and Nennstiel, H. J. (1971). Chimärismus vom Typ $\mathrm{O} / \mathrm{B}$ in zwei neuentdeckten Fällen mit Differenz der LewisGruppen und der Antigenstärken von $\mathrm{H}$ und $\mathrm{P}_{1}$. Blut, 22, 229236.

Race, R. R. and Sanger, R. (1968). Blood Groups in Man. Blackwell Scientific, Oxford.

Race, R. R. and Sanger, R. (1972). Blood group mosaics. Haematologia, 6, 63-71.

Rosenfield, R. E., Haber, G. V., Kissmeyer-Nielsen, F., Jack, J. A., Sanger, R., and Race, R. R. (1960). Ge, a very common red cell antigen. British fournal of Haematology, 6, 344-349.

Uchida, I. A., Wang, H. C., and Ray, M. (1964). Dizygotic twins with $\mathrm{XX} / \mathrm{XY}$ chimerism. Nature, 204, 191.

\section{Inherited partial duplication of chromosome No. $15^{*}$}

Summary. A boy with unusual facial appearance and mental retardation was found to have duplication for the distal half of the long arm of chromosome No. 15 and possibly deficiency for the distal end of the long arm of No. 21. The chromosome abnormality was inherited from his mother, who had a translocation involving chromosomes Nos. 15 and 21. Giemsa-banding localized the break point in chromosome No. 15 just distal to the intense band at the midportion of the long arm. The break point in chromosome No. 21 appeared to be at the distal end of the long arm. The difficulty encountered in cytogenetic analysis of the propositus with conventional staining, the importance of chromosome analysis of the parents, and the application of differential staining techniques are also presented.

There are five reported cases in which partial trisomy of chromosome No. 15 has been diagnosed (Magenis et al, 1972; Parker and Alfi, 1972; Bucher et al, 1973; Crandall, Muller, and Bass, 1973). Using differential staining techniques, these authors interpreted the extra G-like chromosome as a partially deleted chromosome No. 15 and, therefore, the patient was trisomic for the proximal portion of chromosome No. 15.

This present case is a child with confirmed partial duplication of the distal half of the long arm of chromosome No. 15 and probable deficiency for the distal end of the long arm of chromosome No. 21 . This duplication-deficiency abnormality is the result of an unbalanced segregation product inherited from his mother, who is a balanced translocation carrier.

\section{Case history}

This $2980 \mathrm{~g}$ male infant was born at term to a 30-yearold gravida V, para II, ab II, Spanish-American woman. The mother took $120 \mathrm{mg}$ of Armour Thyroid tablet ${ }^{(\mathrm{R})}$ (animal thyroid extract) daily for hypothyroidism since the age of 18. During the fourth month of this pregnancy she had painless vaginal bleeding.

\footnotetext{
Received 19 November 1973.

* This study was supported in part by Grant No. 286 from Maternal and Child Health Service, United States Public Health Service.
} 